fraction are compatible with so called vasomotor nephropathy as the cause of renal failure. ${ }^{2}$ Perhaps the differences in renal haemodynamic properties between $\beta$ blockers and the $\alpha$ and $\beta$ blocker labetalol lead more readily to acute renal failure after an overdose of labetalol. Hypotension leading to acute oliguric renal failure is accompanied by intense preglomerular vasoconstriction, which makes filtration highly dependent on an adequately maintained postglomerular resistance. ${ }^{2}$ In therapeutic doses labetalol leads to a fall in renal vascular resistance; this is in contrast with most $\beta$ blockers, which cause an increase. ${ }^{34} \mathrm{~A}$ fall in postglomerular resistance induced by labetalol, perhaps enhanced by the renal vasodilating effects of dopamine in the dose used in our patient, may have been responsible for the failure of filtration.

1 Prichard BNC, Battersby LA, Cruickshank JM. Overdosage with beta-adrenergic blocking agents. Adverse Drug React Acute Poisoning Rev 1984;3:91-111.

2 Oken DE. Hemodynamic basis for human acute renal failure (vasomotor nephropathy). Am $\mathcal{f}$ Med 1984;76:702-10.

3 Malini PL, Strocchi E, Negroni S, Ambrosioni E, Magnani B. Renal haemodynamics after chronic treatment with labetalol and propranolol. Br 7 Clin Pharmacol 1982;13:123-6S.

4 Bauer JH, Brooks CS. The long-term effect of propranolol therapy on renal function. Am $\mathrm{f} \mathrm{Med}$ 1970;66:404-10.

5 Wee PM ter, Smit AJ, Rosman JB, Sluiter WJ, Donker AJM. Effect of intravenous infusion of lowdose dopamine on renal function in normal individuals and in patients with renal disease. $A m \mathcal{J}$ Nephrol 1986;6:42-6.

(Accepted 4 August 1986)

Division of Nephrology and Intensive Care Unit, Department of Medicine, State University Hospital of Groningen, Groningen, The Netherlands

A J SMIT, MD, registra

PO M MULDER, MD, consultant physician

P E DE JONG, MD, consultant nephrologist

G K VAN DER HEM, MD, professor of nephrology

Correspondence to: Dr Smit.

\section{Endoscopic removal of pharmacobezoar of slow release theophylline}

Overdose with slow release theophylline preparations can result in sustained toxic serum concentrations and is therefore associated with appreciable morbidity and mortality. We report a case of such an overdose in which absorption of the drug and systemic toxicity were further prolonged by aggregation of tablets in the stomach.

\section{Case report}

An 18 year old woman presented to the casualty department having taken abou 60 of her mother's $300 \mathrm{mg}$ slow release theophylline tablets (Theo-Dur, Fison UK Ltd) two to three hours previously. On examination she was flushed, tremulous, and agitated but fully conscious. Electrocardiographic monitoring showed a sustained sinus tachycardia of 132 beats $/ \mathrm{min}$. Hypokalaemia was noted the serum potassium concentration being $2.5 \mathrm{mmol}(\mathrm{mEq}) / 1$. The serum theophylline concentration was $350 \mu \mathrm{mol} / 1(63 \mathrm{mg} / \mathrm{l})$ (therapeutic range 55-110 umol/l; $(10-20 \mathrm{mg} / \mathrm{l}))$. Gastric lavage with a wide bore tube failed to yield any tablet particles. Activated charcoal $(50 \mathrm{~g})$ was then administered orally. Physiological saline and potassium chloride were infused intravenously at rates of $100 \mathrm{ml} / \mathrm{h}$ and $7 \mathrm{mmol}(\mathrm{mEq}) / \mathrm{h}$, respectively. Over the next 12 hours she became more agitated and tremulous, her heart rate increased to $150-160$ beats $/ \mathrm{min}$, and she developed persistent vomiting. The theophylline concentration 12 hours after admission had risen to $490 \mu \mathrm{mol} / 1(88 \mathrm{mg} / \mathrm{l})$. Gastroscopy with a GIFQ endoscope (Key Med Instruments, Southend on Sea), was carried out under diazepam sedation and showed a white, friable bolus of congealed tablets $2 \mathrm{~cm}$ in diameter lying on the greater curvature of the stomach. This was grasped in a Dormia basket and removed. The stomach was then irrigated by water jet and all visible tablet particles aspirated. After endoscopy $20 \mathrm{~g}$ mannitol in 2 litres of water was administered orally over two hours. Three hours after endoscopy the theophylline concentration had fallen to $312 \mu \mathrm{mol} / \mathrm{l}(56 \mathrm{mg} / \mathrm{l})$. Over the next 12 hours her symptoms abated and both heart rate (figure) and serum potassium concentration returned to normal. She remained free of symptoms thereafter.

\section{Comment}

Overdose with any preparation containing theophylline may not only result in distressing vomiting, tremor, and agitation but cause profound hypokalaemia, generalised convulsions, and serious cardiac arrhythmias, mortality as high as $50 \%$ being reported. ${ }^{1}$ Delayed absorption from slow release preparations will prolong and may postpone toxic effects; absorption of Theo-Dur, for example, continues for up to 24 hours after ingestion. ${ }^{2}$ Perhaps as a consequence of the resultant prolonged exposure to the

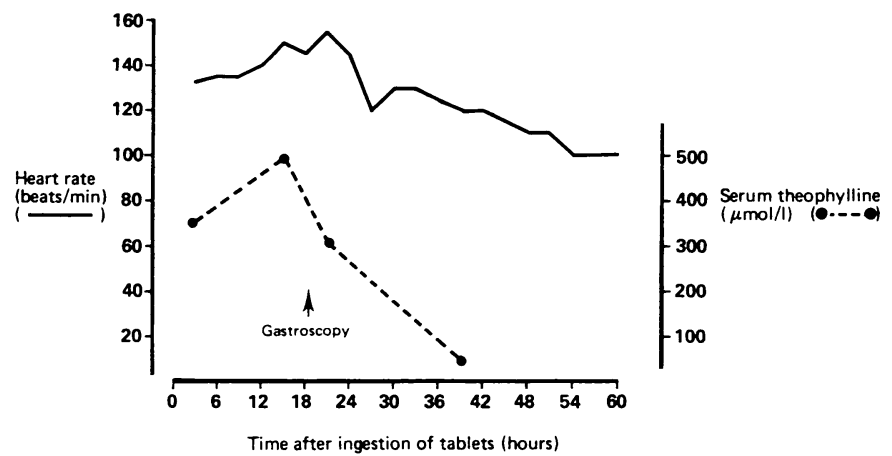

Heart rate and serum theophylline concentration before and after gastroscopic removal of tablet bezoar.

Conversion: SI to traditional units-Serum theophylline: $1 \mu \mathrm{mol} / \mathrm{l} \approx 0 \cdot 18 \mathrm{mg} / \mathrm{l}$.

stimulant effects of theophylline a fatal outcome has been reported after ingestion of as little as $6 \mathrm{~g}$ of the slow release preparation. An intragastric aggregation of tablets, with consequent gradual leaching of active drug from the "bezoar," as described in this case, may further delay absorption and prolong the duration of toxicity.

The formation of similar intragastric concretions or bezoars has been reported after ingestion of meprobamate and aluminium hydroxide in large quantities, as in overdose..$^{3-5}$ In such circumstances gastric lavage, even if performed soon after ingestion of the drug, as in this case, will prove ineffective in removing the drug from the stomach. The rapid fall in theophylline concentration and heart rate seen in this case after endoscopic removal of the tablet bolus suggests that this manoeuvre was highly effective in preventing further absorption of the drug, for otherwise the serum theophylline concentration would have continued to rise for at least a further 12 hours. We therefore propose that endoscopy should be considered in cases of overdose of slow release theophylline in which clinical signs and serial theophylline concentrations suggest continuing drug absorption.

We thank Dr H Cohen for permission to report on his patient, the staff of the gastrointestinal endoscopy unit for their help, and Mrs J Rostron for expert secretarial help.

1 Zwillich CW, Sutton FD, Neff TA, et al. Theophylline induced seizures in adults. Ann Intern Med 1975;82:784-7.

2 Weinberger $M$, Hendeles $L$. Slow-release theophylline. Rationale and basis for product selection. N Engl F Med 1983;308:760-4.

3 Schwartz HS. Acute meprobamate poisoning with gastrostomy and removal of a drug containing mass. N Engl I Med 1976;295:1177-8.

4 Korenman MD, Stubbs MB, Fish JC. Intestinal obstruction from medication bezoars. JAMA 1978:240:54-5.

Townsend CM, Remmers AR, Sarles HE. Intestinal obstruction from medication bezoars in patients with renal failure. N Englf M Med 1973;288: 1058-9.

(Accepted 8 August 1986)

Department of Medicine, Hope Hospital (University of Manchester School of Medicine), Salford M6 8HD

JEAN-MICHEL CEREDA, MD, research fellow

JANET SCOTT, MB, CHB, senior house officer

EAMONN M M QUIGLEY, MD, MRCP, lecturer in medicine

Correspondence to: Dr Quigley.

\section{Imaging in rheumatoid arthritis using liposomes labelled with technetium}

Liposomes are small microscopic spheres composed of one or more concentric phospholipid bilayers. ${ }^{1}$ After intravenous injection they are taken up by the cells of the reticuloendothelial system and are found mainly in the Kupffer cells of the liver and the macrophages of the bone marrow and spleen. As the synovial tissue of patients with rheumatoid arthritis is rich in phagocytic cells we undertook a preliminary study to determine whether radiolabelled liposomes would identify joints affected by rheumatoid disease.

\section{Patients, methods, and results}

We studied two control subjects and eight patients with rheumatoid arthritis (six with active and two with inactive disease). Patients with active disease had 
clinically evident synovitis, and all patients fulfilled the criteria of the American Rheumatism Association ${ }^{2}$ Negatively charged liposomes were injected intravenously after radiolabelling with technetium. ${ }^{3}$ Each patient received $380 \mathrm{MBq}$ $(380 \mathrm{mCi})$ technetium, and joint scanning was performed at $20-22$ hours with an IgE $400 \mathrm{~A}$ gammacamera with a general purpose parallel whole beam collimator.

Scans at four hours showed accumulation of radioactivity in the liver and spleen but little accumulation within synovial tissue. Lateral views of the knee at four hours (figure $(a)$ ) and 20 hours (figure $(b)$ ) showed persistence of activity in bone marrow, a reduction in the activity within blood vessels, and enhanced
Although our results are consistent with the idea that the accumulation of isotope represents endocytosis of liposomes by phagocytic cells, another possibility has to be considered. It is known that liposomes interact with plasma proteins, and as we did not show that the isotope remains attached to the surface of the liposomes after injection we cannot formally exclude the possibility that the scans show the distribution of isotope that has leached from the surface of the liposomes and become associated with other serum proteins. ${ }^{5}$ Nevertheless, we believe that these observations indicate that this
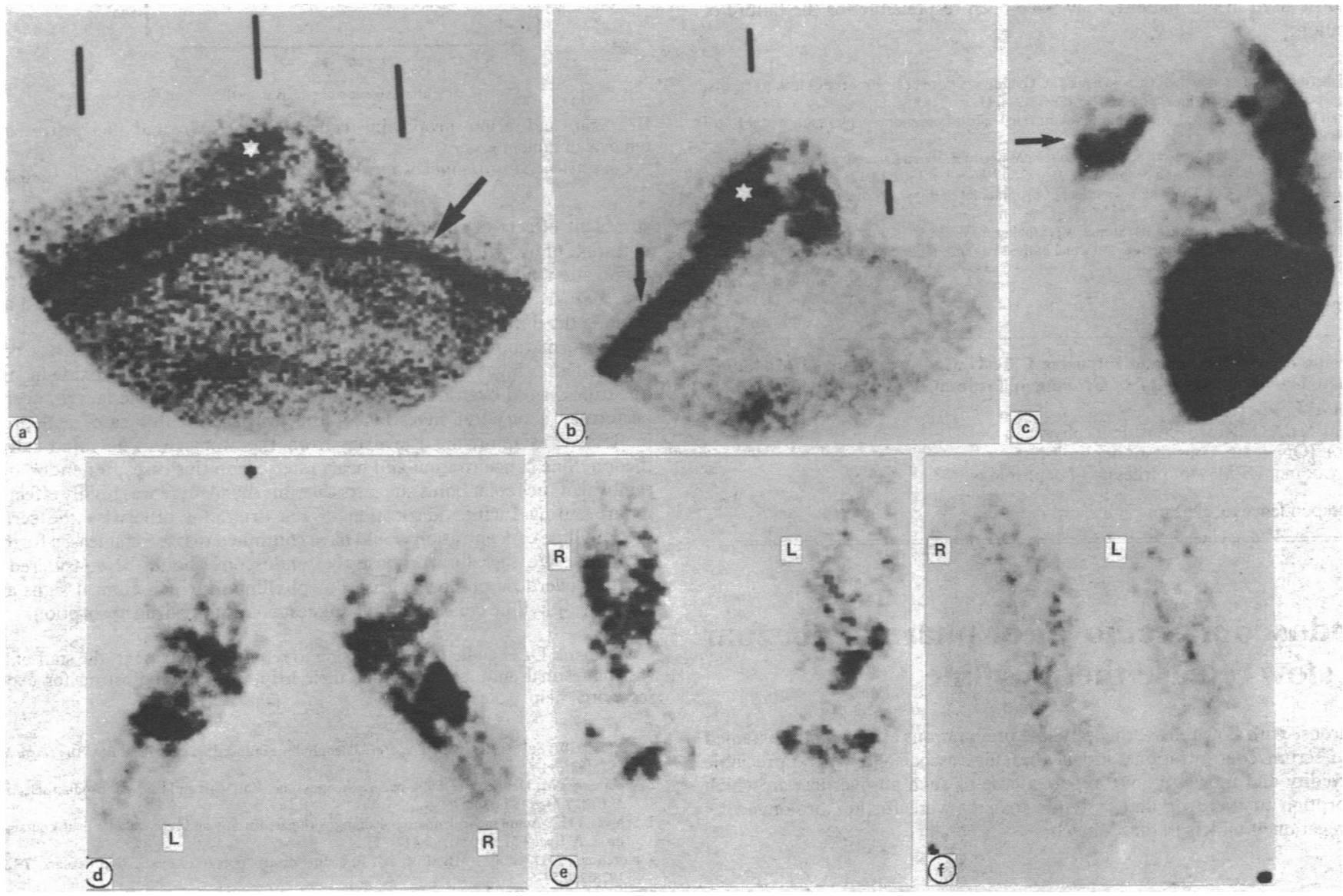

Scintigraphs: (a) scan at four hours, showing lateral view of knee of patient with rheumatoid arthritis, with radioactivity within blood vessel (arrow) and synovium (asterisk); $(b)$ scan in same patient at 20 hours, showing radioactivity within bone marrow (arrow) and synovium (asterisk); (c) scan of shoulder in rheumatoid arthritis; $(d)$ scan of hands in rheumatoid arthritis; $(e)$ scan of feet in rheumatoid arthritis; $(f)$ scan of feet of normal control.

accumulation of the isotope over the knee joint. Aspiration of synovial fluid from the knee joint did not change the appearance of the scan or the degree of radioactivity detectable by superficial counting over the knee. There were clear differences between the patients and controls. Focal accumulation of isotope was shown in the shoulders, elbows, wrists, ankles, and feet. The small proximal interphalangeal joints of the hands, however, even though inflamed clinically, often proved difficult to visualise. Patients with clinically inactive disease did not yield a positive scan (figure $(f)$ ).

\section{Comment}

This study showed that after injection of radiolabelled liposomes the isotope accumulated in clinically affected joints of patients with rheumatoid arthritis. When the disease was in remission and there was no active synovitis accumulation of the isotope did not occur.

Similar studies to ours have been performed in patients with malignant disease in an attempt to identify accumulation of macrophages around tumour tissue. These studies were unsuccessful, and good definition of malignant tissue was not achieved. ${ }^{4}$ Our success in showing radioactivity in rheumatoid synovium may have been because we used small liposomes that were removed only slowly from the circulation and because of the occurrence in synovial tissue of phagocytes, which would serve as natural targets for the injected liposomes. By sequentially sampling synovial fluid after the intravenous injection of liposomes we were able to show that they rapidly gained access into the synovial fluid. Scans at 20 hours that were positive were not the result of passive accumulation of isotope within the synovial fluid. method offers an opportunity of determining the extent and activity of macrophages within synovial tissue and might even be used to optimise the delivery of agents that could subsequently modify the function of macrophages.

1 Gregoriadis G. The carrier potential of liposomes in biology and medicine. $N$ Engl $\mathcal{J}$ Med 1976;295:704-10,765-77.

2 Ropes MW, Bennett GA, Cobb S, Jacox R, Jessar RA. Revision of the diagnostic criteria for rheumatoid arthritis. Bull Rheum Dis 1958;9:175-6.

3 Morgan JR, Williams IA, Howard CB. Technetium labelled liposome imaging for deepseated infection BrF Radiol 1985.58:35-9.

4 Richardson VJ, Ryman BE, Jewkes RF, et al. Tissue distribution and tumour localization of 99m technetium labelled liposomes in cancer patients. Br $f$ Cancer 1979;40:35-43.

5 Scherphof GD, Damen J, Hoekstra D. Interactions of liposomes with plasma proteins and components of the immune system. In: Knight CG, ed. Liposomes from physical structure to therapeutic applications. Amsterdam: Elsevier/North Holland, 1981:299-322.

(Accepted 16 fuly 1986)

\section{University Hospital of Wales, Cardiff CF4 4XW}

B D WILLIAMS, FRCP, department of medicine

M M O'SULLIVAN, MRCP, senior registrar, department of rheumatology

G S SAGGU, MSC, department of medical physics

K E WILLIAMS, BSC, department of medical microbiology

L A WILLIAMS, FRCS, FRCR, consultant, department of radiology

J R MORGAN, PHD, department of medical microbiology

Correspondence and requests for reprints to: Dr B D Williams, Rheumatology Research Centre, University Hospital of Wales, Cardiff CF4 4XW. 